\title{
Syntheses, structure and properties of Alkaline-earth metal salts of 4-Nitrophenylacetic acid
}

\author{
BIKSHANDARKOIL R SRINIVASAN ${ }^{\mathrm{a}, *}$, KIRAN T DHAVSKAR ${ }^{\mathrm{a}}$ and CHRISTIAN NÄTHER ${ }^{\mathrm{b}}$ \\ ${ }^{a}$ Department of Chemistry, Goa University, Goa 403 206, India \\ bInstitut für Anorganische Chemie, Christian-Albreschts Universität Kiel, D-24098 Kiel, Germany \\ e-mail: srini@unigoa.ac.in
}

MS received 31 May 2016; revised 28 July 2016; accepted 28 August 2016

\begin{abstract}
The synthesis, crystal structure, spectral characteristics and thermal properties of alkaline-earth metal salts of 4-nitrophenylacetic acid (4-npaH) namely, $\left[\mathrm{Mg}\left(\mathrm{H}_{2} \mathrm{O}\right)_{6}\right](4-\mathrm{npa})_{2} \cdot 4 \mathrm{H}_{2} \mathrm{O}$ (4-npa = 4-nitrophenylacetate) (1), $\left[\mathrm{Ca}\left(\mathrm{H}_{2} \mathrm{O}\right)_{2}(4-n p a)_{2}\right](2)$ and $\left[\mathrm{Sr}\left(\mathrm{H}_{2} \mathrm{O}\right)_{3}(4-n p a)_{2}\right] \cdot 4.5 \mathrm{H}_{2} \mathrm{O}(3)$ are reported. In 1, the 4-npa ion functions as a charge balancing counter anion for the octahedral $\left[\mathrm{Mg}\left(\mathrm{H}_{2} \mathrm{O}\right)_{6}\right]^{2+}$ unit with the $\mathrm{Mg}(\mathrm{II})$ ion situated on a centre of inversion. The two unique lattice water molecules link the $\left[\mathrm{Mg}\left(\mathrm{H}_{2} \mathrm{O}\right)_{6}\right]^{2+}$ cations and 4-npa anions with the aid of $\mathrm{O}-\mathrm{H} \cdots \mathrm{O}$ interactions. Compounds $\mathbf{2}$ and $\mathbf{3}$ are one-dimensional (1-D) coordination polymers containing an eight coordinated $\mathrm{Ca}(\mathrm{II})$ situated in a general position and a nine coordinated $\mathrm{Sr}(\mathrm{II})$ located on a twofold axis. The $\mu_{2}$-bridging tridentate binding modes of the crystallographically independent 4-npa ligands in $\mathbf{2}$ and the unique 4-npa ligand in $\mathbf{3}$ link the bivalent metal ions into an infinite chain with alternating $\mathrm{Ca} \cdots \mathrm{Ca}$ separations of 3.989 and $4.009 \AA$, respectively, and a single $\mathrm{Sr} \cdots$ Sr separation of $4.194 \AA$ in the 1-D chain.
\end{abstract}

Keywords. Alkaline-earth; 4-nitophenylacetic acid; one-dimensional; $\mu_{2}$-bridging tridentate; coordination polymer.

\section{Introduction}

The past two decades have witnessed the development of an extensive s-block metal chemistry in terms of the structural characterization of several alkali and alkaline-earth metal carboxylates. ${ }^{1-8}$ These studies have revealed that the alkaline-earths exhibit different degrees of hydration. Unlike $\mathrm{Mg}$ (II) which forms many compounds containing the octahedral $\left[\mathrm{Mg}\left(\mathrm{H}_{2} \mathrm{O}\right)_{6}\right]^{2+}$ ion, ${ }^{6}$ the heavier congeners contain less number of coordinated water molecules and adopt an extended structure viz., one- or two-dimensional due to carboxylate bridging. The heavier metal ions exhibit a higher coordination number; for example the preferred coordination number of $\mathrm{Ca}(\mathrm{II})$ is eight, ${ }^{8}$ while $\mathrm{Sr}(\mathrm{II})^{3 \mathrm{e}, \mathrm{f}}$ or $\mathrm{Ba}(\mathrm{II})^{5 \mathrm{a}, \mathrm{b}}$ exhibit coordination numbers of nine or more. The flexibility of $\mathrm{Ca}$, Sr and $\mathrm{Ba}$ to adopt variable coordination geometries ${ }^{1 \mathrm{a}, \mathrm{b}}$ and their oxophilic nature are probably responsible for a higher denticity (viz., tridentate or more) of the carboxylate ligand to satisfy the higher than six coordination number of these metal ions, resulting in the formation of extended structures. This was well demonstrated for alkaline-earths by linking them into a one-dimensional (1-D) chain employing 2-aminobenzoic acid as a linker. ${ }^{7 \mathrm{a}}$ An aromatic ring

*For correspondence

Dedicated to Prof. M.S. Wadia on the occasion of his $80^{\text {th }}$ birthday. offers the possibility of disposing the $-\mathrm{COOH}$ group differently by placing additional substituents like $-\mathrm{NH}_{2}$, $-\mathrm{OH},-\mathrm{NO}_{2}$, etc., on the six membered ring to fine tune the structure with the aid of secondary interactions, resulting in a rich structural chemistry for the alkaline-earth metal benzene carboxylates. When synthesis is performed in aqueous medium, the small size, high hydration tendency and a preferred hexa coordination number favour the formation of an octahedral $\left[\mathrm{Mg}\left(\mathrm{H}_{2} \mathrm{O}\right)_{6}\right]^{2+}$ ion charge balanced by carboxylate anion leading to monomeric structures. The $-\mathrm{NO}_{2}$ group is isoelectronic with $-\mathrm{COOH}$ but is devoid of metal binding capabilities. Hence, we have investigated the chemistry of nitrobenzoic acids with alkalineearths. Although 1-D coordination polymers could be constructed using 2-nitrobenzoic acid (2-nbaH), ${ }^{8 \mathrm{~b}}$ 2-carbamoyl-4-nitrobenzoic acid, ${ }^{8 \mathrm{~g}}$ 3-nitrophthalic acid, ${ }^{7 \mathrm{f}}$ only monomeric structures could be assembled for $\mathrm{Ca}^{9 \mathrm{~b}}$ or $\mathrm{Sr}^{9 \mathrm{c}}$ with 4-nitrobenzoic acid (4-nbaH). The introduction of a $-\mathrm{CH}_{2}$ group trans to the nitro functionality between the ring and the $-\mathrm{COOH}$ in 4-nbaH results in 4-nitrophenylacetic acid (4-npaH). In the pair of linkers which differ by a methylene group, the $-\mathrm{COOH}$ moiety (Figure 1) is attached to a rigid six membered ring in 4-nbaH while it is more flexible in 4-npaH. In the literature few papers are reported on metal 4-nitrophenylacetate (4-npa) compounds other than 


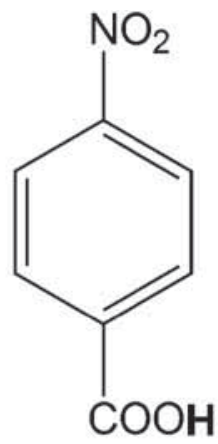

\section{4-nitrobenzoic acid (4-nbaH) \\ 4-nitrophenylacetic acid (4-npaH)}

Figure 1. Rigid versus flexible $-\mathrm{COOH}$ group in 4-nbaH and 4-npaH.

alkaline earths. ${ }^{10}$ In this study, we have investigated the reactions of alkaline-earth carbonates with 4-npaH to structurally characterize the products. The results are described in this paper.

\section{Experimental}

\subsection{Materials and methods}

All the chemicals used in this study were of reagent grade and were used as received without any further purification. Infrared (IR) spectra of the solid samples diluted with $\mathrm{KBr}$ were recorded on a Shimadzu (IR Prestige-21) FT-IR spectrometer from $4000-400 \mathrm{~cm}^{-1}$ at a resolution of $4 \mathrm{~cm}^{-1}$. Raman spectra were recorded using $785 \mathrm{~nm}$ laser radiation for excitation on an Agiltron PeakSeeker Pro Raman instrument. UV-Visible spectra were recorded in water using a Shimadzu UV-2450 double beam spectrophotometer using matched quartz cells. Isothermal weight loss studies were performed in a temperature controlled furnace. TG-DTA study was performed in flowing oxygen in $\mathrm{Al}_{2} \mathrm{O}_{3}$ crucibles at heating rate of $10 \mathrm{~K} \mathrm{~min}^{-1}$ using a STA-409 PC simultaneous thermal analyser from Netzsch. Elemental analyses $(\mathrm{C}, \mathrm{H}$ and $\mathrm{N}$ ) were performed on a Variomicro cube CHNS analyser.

2.2 Synthesis of $\left[\mathrm{Mg}\left(\mathrm{H}_{2} \mathrm{O}\right)_{6}\right](4-n p a)_{2} \cdot 4 \mathrm{H}_{2} \mathrm{O}(\mathrm{I}),[\mathrm{Ca}$ (4-npa $\left.)_{2}\left(\mathrm{H}_{2} \mathrm{O}\right)_{2}\right](2),\left[\mathrm{Sr}(4-n p a)_{2}\left(\mathrm{H}_{2} \mathrm{O}\right)_{3}\right] \cdot 4.5 \mathrm{H}_{2} \mathrm{O}(3)$, and $\left[\mathrm{Ba}(4-n p a)_{2}\left(\mathrm{H}_{2} \mathrm{O}\right)\right](4)$

A mixture of 4-npaH $(1.812 \mathrm{~g}, 10 \mathrm{mmol})$ and magnesium carbonate $(5 \mathrm{mmol})$ was taken in distilled water $(\sim 100 \mathrm{~mL})$ and the reaction mixture was heated on a water bath. The insoluble starting material slowly started dissolving with brisk effervescence. The heating was stopped when there was no more evolution of $\mathrm{CO}_{2}$. At this stage, the reaction mixture was almost clear, and $\mathrm{pH}$ was close to neutral. The hot reaction mixture was filtered and kept aside for crystallization at low temperature. Colourless crystals of $\mathbf{1}$ which separated in a few days were collected by filtration in $\sim 60 \%$ yield. The use of calcium carbonate, strontium carbonate and barium carbonate instead of $\mathrm{MgCO}_{3}$ in the above reaction afforded compounds $\mathbf{2}, \mathbf{3}$ and $\mathbf{4}$, respectively. (Yield $=65-72 \%$ ) Anal. Calcd $(\%)$ for $\mathrm{C}_{16} \mathrm{H}_{32} \mathrm{MgN}_{2} \mathrm{O}_{18}$ (564.74 g/mol) 1: C, 34.03; H, 5.71; N, 4.96; MgO, 7.14; Found (\%): C, 34.02.17; H, 5.59; N, 4.51; MgO, 7.38; Anal. Calcd(\%) for $\mathrm{C}_{16} \mathrm{H}_{16} \mathrm{CaN}_{2} \mathrm{O}_{10}(436.39 \mathrm{~g} / \mathrm{mol}) 2$ : C, 44.04; H, 3.70; N, 6.42; $\mathrm{CaCO}_{3}$, 22.93; Found(\%): C, 44.99; $\mathrm{H}, 3.72 ; \mathrm{N}, 6.11 ; \mathrm{CaCO}_{3}, 21.31 ;$ Anal.Calcd(\%) for $\mathrm{C}_{16} \mathrm{H}_{27} \mathrm{SrN}_{2} \mathrm{O}_{15.5}(583.01 \mathrm{~g} / \mathrm{mol}) 3: \mathrm{C}, 32.96 ; \mathrm{H}, 4.68$; N, 4.80; $\mathrm{SrCO}_{3}$, 23.10; Found: C, 33.29; H, 4.476; N, 4.79; $\mathrm{SrCO}_{3}, 24.95$; Anal. $\mathrm{Calcd}(\%)$ for $\mathrm{C}_{16} \mathrm{H}_{14} \mathrm{BaN}_{2} \mathrm{O}_{9}$ (515.62 g/mol) 4: $\mathrm{H}_{2} \mathrm{O}, 3.40 ; \mathrm{BaCO}_{3}, 38.27$; Found(\%): $\mathrm{H}_{2} \mathrm{O}, 3.49 ; \mathrm{BaCO}_{3}, 38.13$.

\section{$2.3 X$-ray crystal structure determination}

Single crystal X-ray structure analysis of $\mathbf{1}$ and $\mathbf{3}$ was performed at the Sophisticated Analytical Instrument Facility (SAIF), Indian Institute of Technology (IIT) Madras. Intensity data were collected using Bruker AXS Kappa Apex II CCD Diffractometer for $\mathbf{1}$ and 3 and an Image Plate Diffraction System (IPDS-1) from STOE for 2. The structures were solved with direct methods using SHELXS-97 and refinement was done against $\mathrm{F}^{2}$ using SHELXL-97. ${ }^{11}$ All non-hydrogen atoms were refined anisotropically. All hydrogen atoms attached to the aromatic ring were introduced in calculated positions and included in the refinement by riding on their respective parent $\mathrm{C}$ atoms. The $\mathrm{O}-\mathrm{H}$ and $\mathrm{N}-\mathrm{H}$, hydrogen atoms were located in difference map, their bond lengths were set to ideal values (for 2) and afterwards they were refined using a riding model. The technical details of data acquisition and selected crystal refinement results are summarised in Table 1.

\section{Results and Discussion}

\subsection{Synthetic aspects, spectral and thermal studies}

The reaction of alkaline-earth metal carbonates $\mathrm{MCO}_{3}$ $(\mathrm{M}=\mathrm{Mg}$ or $\mathrm{Ca}$ or $\mathrm{Sr}$ or $\mathrm{Ba}$ ) with 4-npaH in 1:2 mole ratio in a hot aqueous solution resulted in the dissolution of $\mathrm{MCO}_{3}$. Filtration followed by slow evaporation 
Table 1. Crystal data and selected refinement results for (1), (2), and (3).

\begin{tabular}{|c|c|c|c|}
\hline Empirical formula & $\mathrm{C}_{16} \mathrm{H}_{32} \mathrm{~N}_{2} \mathrm{MgO}_{18}(\mathbf{1})$ & $\mathrm{C}_{16} \mathrm{H}_{16} \mathrm{~N}_{2} \mathrm{CaO}_{10}$ & $\mathrm{C}_{16} \mathrm{H}_{27} \mathrm{~N}_{2} \mathrm{SrO}_{155}(\mathbf{3})$ \\
\hline Formula weight $(\mathrm{g} / \mathrm{mol})$ & 564.74 & 436.39 & 583.01 \\
\hline Temperature (K) & $293(2)$ & $200(2)$ & $293(2)$ \\
\hline Wavelength $(\AA)$ & 0.71073 & 0.71073 & 0.71073 \\
\hline Crystal system & Monoclinic & Triclinic & Monoclinic \\
\hline Space group & $P 2_{1} / c$ & $P \overline{1}$ & $C 2 / c$ \\
\hline \multicolumn{4}{|l|}{ Unit cell dimensions } \\
\hline$a(\AA)$ & $13.5398(9)$ & $7.7599(8)$ & $29.118(4)$ \\
\hline$b(\AA)$ & $8.1318(5)$ & $10.9920(12)$ & $11.2307(16)$ \\
\hline$c(\AA)$ & 11.8364(9) & $12.1866(14)$ & $7.9877(11)$ \\
\hline$\alpha\left({ }^{\circ}\right)$ & 90 & $108.538(13)$ & 90 \\
\hline$\beta\left({ }^{\circ}\right)$ & $102.042(3)$ & $105.120(12)$ & $100.988(6)$ \\
\hline$\gamma\left({ }^{\circ}\right)$ & 90 & $90.597(12)$ & 90 \\
\hline Volume $\left(\AA^{3}\right)$ & $1274.54(15)$ & $946.46(18)$ & $2564.2(6)$ \\
\hline $\mathrm{Z}$ & 2 & 2 & 4 \\
\hline $\mathrm{D}_{\text {calc }}\left(\mathrm{mg} / \mathrm{m}^{3}\right)$ & 1.472 & 1.531 & 1.497 \\
\hline Absorption coefficient $\left(\mathrm{mm}^{-1}\right)$ & 0.156 & 0.391 & 2.175 \\
\hline$F(000)$ & 596 & 452 & 1196 \\
\hline Crystal size $\left(\mathrm{mm}^{3}\right)$ & $0.35 \times 0.30 \times 0.25$ & $0.18 \times 0.12 \times 0.07$ & $0.08 \times 0.05 \times 0.04$ \\
\hline$\theta$ range for data collection $\left(^{\circ}\right)$ & 2.940 to 24.996 & 2.73 to 27.00 & 2.804 to 24.996 \\
\hline Index ranges & $-15 \leq h \leq 16$ & $-9 \leq h \leq 9$ & $-34 \leq h \leq 27$ \\
\hline \multirow{4}{*}{ Reflections collected / unique } & $-9 \leq k \leq 9$ & $-14 \leq k \leq 14$ & $-13 \leq k \leq 13$ \\
\hline & $-14 \leq l \leq 14$ & $-15 \leq l \leq 15$ & $-9 \leq l \leq 9$ \\
\hline & $1387 \overline{2} / 2 \overline{2} 39$ & $8221 / 40 \overline{19}$ & $183 \overline{21} 1 / \overline{2} 267$ \\
\hline & {$[\mathrm{R}(\mathrm{int})=0.0351]$} & {$[\mathrm{R}(\mathrm{int})=0.0646]$} & {$[\mathrm{R}(\mathrm{int})=0.1290]$} \\
\hline Reflections with $\mathrm{I}>2 \sigma(\mathrm{I})$ & 1716 & 2769 & 1515 \\
\hline Completeness to $\theta$ & $100 \%$ & $97.2 \%$ & $99.9 \%$ \\
\hline Absorption correction & Semi-empirical from equivalents & Numerical & Semi-empirical from equivalents \\
\hline Max. and min. Transmission & 0.975 and 0.937 & 0.8818 and 0.9678 & 0.895 and 0.802 \\
\hline Data / restraints / parameters & $2239 / 16 / 209$ & $4019 / 0 / 263$ & $2266 / 5 / 173$ \\
\hline Goodness-of-fit on $\mathrm{F}^{2}$ & 1.029 & 0.957 & 1.003 \\
\hline Final $\mathrm{R}$ indices $[\mathrm{I}>2 \sigma(\mathrm{I})]$ & $\begin{array}{l}\mathrm{R} 1=0.0406 \\
\mathrm{wR} 2=0.0795\end{array}$ & $\begin{array}{l}\mathrm{R} 1=0.0405 \\
\mathrm{wR} 2=0.0887\end{array}$ & $\begin{array}{l}\mathrm{R} 1=0.0433 \\
\mathrm{wR} 2=0.1072\end{array}$ \\
\hline $\mathrm{R}$ indices (all data) & $\begin{array}{l}\mathrm{R} 1=0.0610 \\
\mathrm{wR} 2=0.0875\end{array}$ & $\begin{array}{l}\mathrm{R} 1=0.0744, \\
\mathrm{wR} 2=0.1010\end{array}$ & $\begin{array}{l}\mathrm{R} 1=0.0886 \\
\mathrm{wR} 2=0.1280\end{array}$ \\
\hline Largest diff. peak and hole $\left(\mathrm{e} \AA^{-3}\right)$ & 0.240 and -0.194 & 0.347 and -0.369 & 0.447 and -0.301 \\
\hline
\end{tabular}

of the reaction mixture afforded compounds 1-4 in good yield. Out of these, 1-3 gave crystals suitable for $\mathrm{X}$-ray structure determination; only a polycrystalline material could be obtained for 4 . Hence, for compound 4 with a composition $\left[\mathrm{Ba}(4-n p a)_{2}\left(\mathrm{H}_{2} \mathrm{O}\right)\right]$, the structure could not be determined. An analysis revealed that all compounds which contain metal:4-npa in 1:2 ratio are differently hydrated with the metal:water ratios being 1:10, 1:2, 1:7.5 and 1:1 for $\mathrm{Mg}, \mathrm{Ca}, \mathrm{Sr}$ and $\mathrm{Ba}$, respectively.

A comparison of the IR spectra (Figure S1 in Supplementary Information) of fresh samples of 1-4 with 4-npaH, reveals that the band due to $-\mathrm{COOH}$ group of the free acid occurring at $1710 \mathrm{~cm}^{-1}$ is shifted to lower energies in 1-4 due to the formation of metal carboxylate. The presence of water in $\mathbf{1 - 4}$ can be evidenced by the characteristic profile of the spectra in the $3500-3000 \mathrm{~cm}^{-1}$ region. However, it is found that compounds $\mathbf{1}$ and $\mathbf{3}$ tend to lose water gradually with time. Compound $\mathbf{1}$ loses its lattice water once air dried as evidenced by changes in IR spectra (Figure S2 in Supplementary Information), and TGDTA curves (Figure 2) of air dried sample of $\mathbf{1}$.

A weight loss of $21.94 \%$ above $100^{\circ} \mathrm{C}$ accounts for weight loss of six coordinated water, instead of ten if lattice water is considered. This suggests that the lattice waters of the compound $\mathbf{1}$ are more easily lost when subjected to dryness. Hence, the first DTA endothermic peak is assigned to the removal of coordinated water. The DTA peak at $557^{\circ} \mathrm{C}$ is an exothermic event and represents the decomposition of complex into its oxide with the observed residue of $7.38 \%$ in agreement with the calculated value of $7.14 \%$. Similarly, 3 also loses water over a period of time but slower than $\mathbf{1}$. 


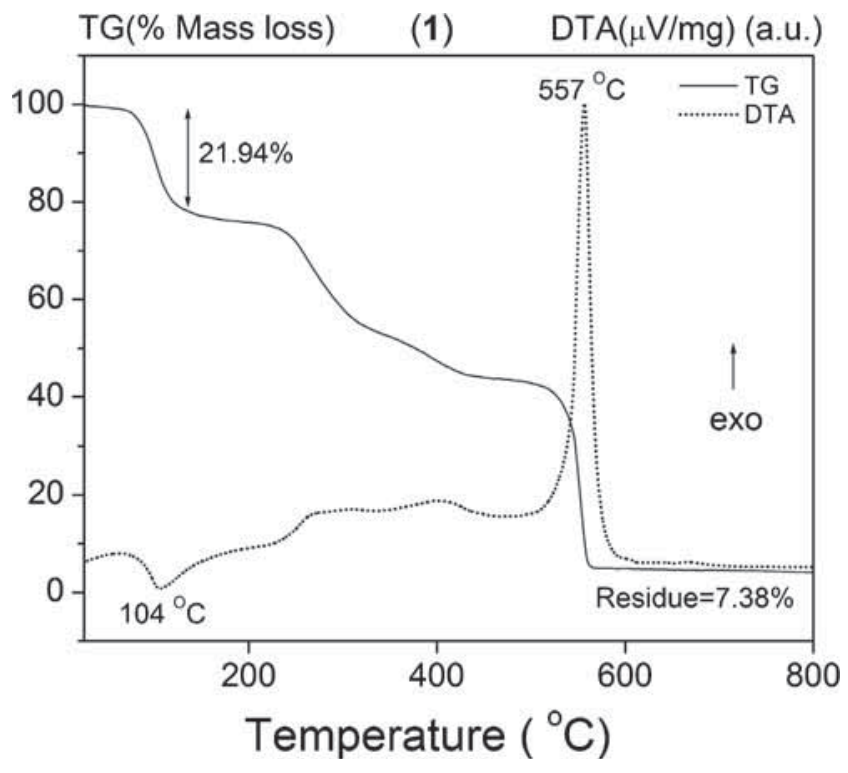

Figure 2. TG-DTA curves for 1 at $10^{\circ} \mathrm{C} / \mathrm{min}$.

This behaviour is clearly evidenced from differences observed in TG profile of freshly air dried and aged (or old) sample of $\mathbf{3}$ (Figure S3 in Supplementary Information). A fresh sample shows total weight loss of 23. $27 \%$ accounting for loss of 7.5 moles of water, while an aged sample of $\mathbf{3}$ is comparatively drier as it shows weight loss of only $12.07 \%$ at the same temperature. This change is also observed in the corresponding DTA curves of both samples. In fresh sample of $\mathbf{3}$, two endothermic peaks, at $79^{\circ} \mathrm{C}$ and $130^{\circ} \mathrm{C}$ respectively are observed, while only a single endothermic peak at $126^{\circ} \mathrm{C}$ is observed in the DTA curve of aged sample. The differences appear in the region between 3500$3000 \mathrm{~cm}^{-1}$ of IR spectra of $\mathbf{3}$ (Figure S4 in Supplementary Information) which clearly indicate that the water content in two samples is no more the same. Above $500^{\circ} \mathrm{C}$ the compound is decomposed into its carbonate $\left(\% \mathrm{SrCO}_{3}=24.95 \%\right)$. It is interesting to note that 2 is not only air stable but also doesn't lose any water even at $100^{\circ} \mathrm{C}$. The TG-DTA curves exhibit (Figure S5 in Supplementary Information) an endothermic event at $131^{\circ} \mathrm{C}$ and a corresponding mass loss of $8.45 \%$ which indicates loss of two coordinated water molecules. The stability at $100^{\circ} \mathrm{C}$ and dehydration at $131^{\circ} \mathrm{C}$ is can be evidenced from IR spectra (Figure S6 in Supplementary Information) of compound $\mathbf{2}$, heated at these temperatures. Similarly, compound $\mathbf{4}$ is thermally stable as weight change is observed only when it is heated to $150^{\circ} \mathrm{C}$. The barium carbonate residue formed $(38.13 \%)$ on decomposition of $\mathbf{4}$, indicates the presence of a single water molecule. This is confirmed by a mass loss of $3.40 \%$ (expected for one water $=3.49 \%$ ) observed at $150^{\circ} \mathrm{C}$ for compound $\mathbf{4}$. However, 4 is immediately rehydrated back upon cooling to room temperature. The Raman spectra of 1-3 and the free ligand 4-npaH are very similar (Figure S7 in Supplementary Information). It is interesting to note that compounds $\mathbf{1 - 3}$ exhibit the symmetric stretching vibration of the $-\mathrm{NO}_{2}$ group at $\sim 1339 \mathrm{~cm}^{-1}$ as the most intense signal which is also observed in the free ligand. The asymmetric stretching vibration of the $-\mathrm{NO}_{2}$ group is also observed as a strong signal at $\sim 1597 \mathrm{~cm}^{-1}$. The optical spectra of $\mathbf{1}$ to 3 in water exhibit absorption maxima (Figure S8) which are close to $291 \mathrm{~nm}$, the $\lambda_{\max }$ of the free acid. This signal can thus be assigned for an intra-ligand charge transfer of 4-npa.

\subsection{Description of Crystal structures}

Compound 1 crystallises in the centrosymmetric monoclinic $P 2_{1} / c$ space group with the $\mathrm{Mg}$ (II) located on an inversion centre. The crystal structure consists of a central $\mathrm{Mg}$ (II) ion, three unique terminal water ligands, an independent 4-npa anion and two lattice water molecules (Figure 3). In view of the special position of $\mathrm{Mg}(\mathrm{II})$, the asymmetric unit consists of a half of the formula unit. In this compound, 4-npa is not coordinated to $\mathrm{Mg}(\mathrm{II})$ but functions as a charge balancing counter anion. The metric parameters of the 4-npa anion are in the normal range (Table S1 in Supplementary Information). The central metal is linked to six aqua ligands forming the well-known $\left[\mathrm{Mg}\left(\mathrm{H}_{2} \mathrm{O}\right)_{6}\right]^{2+}$ unit observed in several $\mathrm{Mg}$ (II) carboxylates listed in the Cambridge Database. The Mg-O bond distances range from 2.0510(15) to 2.0855(16) $\AA$ (Table 2). The trans $\mathrm{O}-\mathrm{Mg}-\mathrm{O}$ angles exhibit ideal values of $180^{\circ}$ while the cis $\mathrm{O}-\mathrm{Mg}-\mathrm{O}$ vary between $88.37(7)$ to $91.63(7)^{\circ}$ (Table S2 in Supplementary Information) indicating a slightly distorted $\left\{\mathrm{MgO}_{6}\right\}$ octahedron.

An analysis of the crystal structure of $\mathbf{1}$ reveals that the $\left[\mathrm{Mg}\left(\mathrm{H}_{2} \mathrm{O}\right)_{6}\right]^{2+}$ cations, 4-npa anion and the lattice water are interlinked with the aid of O-H... O interactions (Table 3). The O4, O5 and O6 atoms of the 4-npa anion, and the $\mathrm{O} 8$ and $\mathrm{O} 9$ of the lattice water function as $\mathrm{H}$-acceptors while the $\mathrm{H}$-atoms of the coordinated and lattice water molecules function as H-donors. The O9H9B . . O8 interaction between the lattice waters results in the formation of a water dimer, which is further $\mathrm{H}$ bonded to two symmetry related $\left[\mathrm{Mg}\left(\mathrm{H}_{2} \mathrm{O}\right)_{6}\right]^{2+}$ cations and three different 4-npa anions (Figure 4).

The $\mathrm{O} 8$ of the lattice water forms $\mathrm{H}$-acceptor bonds with a $\left[\mathrm{Mg}\left(\mathrm{H}_{2} \mathrm{O}\right)_{6}\right]^{2+}$ cation via $\mathrm{O} 2-\mathrm{H} 2 \mathrm{C} \cdots \mathrm{O} 8$ and a second lattice water via O9-H9B ... O8 interactions, while the $\mathrm{H}$ atoms of the lattice water further link it with two 4-npa anions via the $\mathrm{H}$-donor bonds O8-H8A . . O5 and O8-H8B...O6 (Figure S9 in Supplementary 

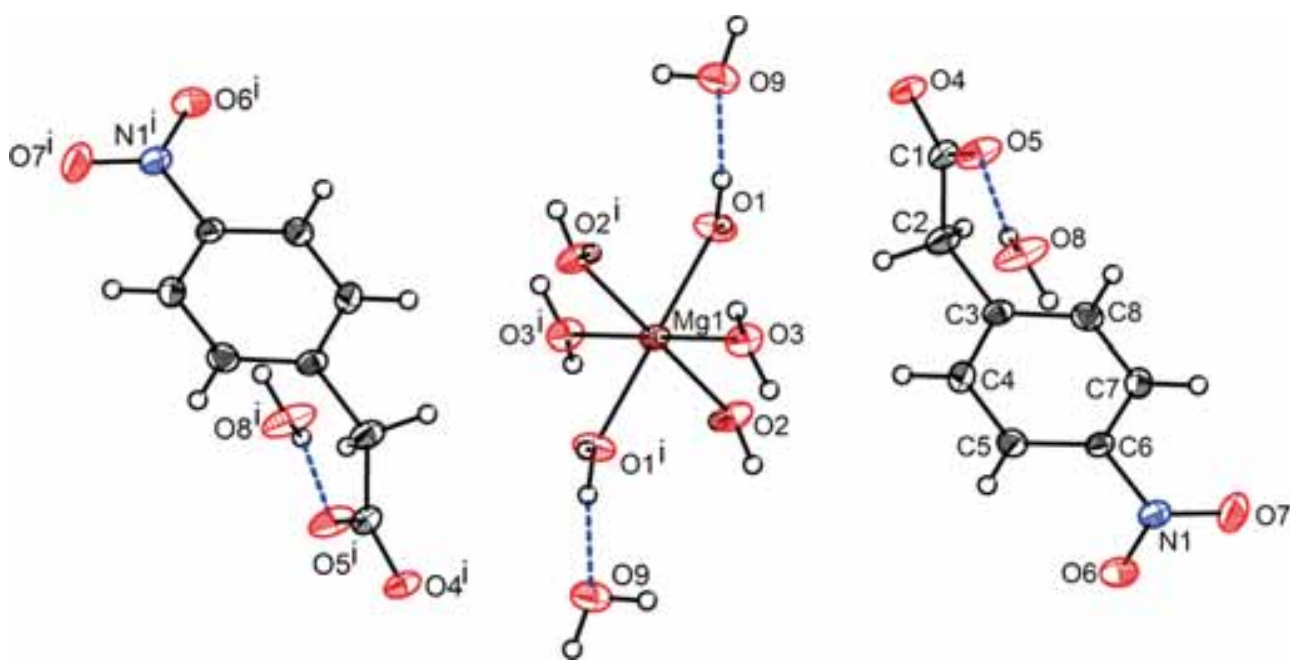

Figure 3. The crystal structure of $\mathbf{1}$ showing the atom labelling scheme and the coordination sphere of $\mathrm{Mg}(\mathrm{II})$. Displacement ellipsoids are drawn at the $50 \%$ probability level excepting for the $\mathrm{H}$ atoms, which are shown as spheres of arbitrary radii. Intramolecular $\mathrm{H}$-bonding is shown in broken lines.

Information). The $\mathrm{O} 9$ of the second lattice water forms $\mathrm{H}$-acceptor bonds with two different $\left[\mathrm{Mg}\left(\mathrm{H}_{2} \mathrm{O}\right)_{6}\right]^{2+}$ cations via $\mathrm{O} 1-\mathrm{H} 1 \mathrm{~A} \cdots \mathrm{O} 9$ and $\mathrm{O} 1-\mathrm{H} 1 \mathrm{~B} \cdots \mathrm{O} 9$ interactions, while the $\mathrm{H}$ atoms of the lattice water further link 4-npa anion and the first lattice water via O9-H9A... $\mathrm{O} 4$ and $\mathrm{O} 9-\mathrm{H} 9 \mathrm{~B} \cdots \mathrm{O} 8$ interactions respectively leading to the formation of alternating layers of cations and anions (Figure S9). Thus the unique lattice water molecules (O8 and O9) linked into a H-bonded dimer serve as a link between the alternating layers of cations and anions.

Compound 2 crystallizes in the centrosymmetric triclinic space group $P \overline{1}$ with all atoms located in general positions. Its structure (Figure 5) consists of an octacoordinated central $\mathrm{Ca}(\mathrm{II})$, two terminal water molecules, and two crystallographically independent 4-npa ligands, both of which behave as $\mu_{2}$-bridging tridentate ligands (Figure S10 in Supplementary Information). The geometric parameters of the unique 4-npa ligands are in the normal range (Table S1). Each calcium is linked to two monodentate water, and to six $\mathrm{O}$ atoms from four symmetry related 4-npa anions, resulting in a distorted square antiprismatic $\left\{\mathrm{CaO}_{8}\right\}$ polyhedron (Figure $\mathrm{S} 10$ in Supplementary Information). The $\mathrm{Ca}-\mathrm{O}$ bond distances vary between $2.3359(16)$ and 2.6636(17) $\AA$ (Table 2) while the $\mathrm{O}-\mathrm{Ca}-\mathrm{O}$ angles scatter in a very broad range

Table 2. Selected bond lengths $[\AA]$ for $\mathbf{1}, \mathbf{2}$, and $\mathbf{3}$.

\begin{tabular}{|c|c|c|c|}
\hline \multicolumn{4}{|c|}{$\left[\mathrm{Mg}\left(\mathrm{H}_{2} \mathrm{O}\right)_{6}\right](4-\mathrm{npa})_{2} \cdot 4 \mathrm{H}_{2} \mathrm{O}(\mathbf{1})$} \\
\hline $\mathrm{Mg} 1-\mathrm{O} 1$ & $2.0855(16)$ & $\mathrm{Mg} 1-\mathrm{O} 1^{\mathrm{i}}$ & $2.0856(16)$ \\
\hline $\mathrm{Mg} 1-\mathrm{O} 2$ & $2.0510(15)$ & $\mathrm{Mg} 1-\mathrm{O} 2^{\mathrm{i}}$ & $2.0510(15)$ \\
\hline Mg1-O3 & $2.0607(15)$ & $\mathrm{Mg} 1-\mathrm{O} 3^{\mathrm{i}}$ & $2.0607(15)$ \\
\hline \multicolumn{4}{|c|}{$\left[\mathrm{Ca}\left(\mathrm{H}_{2} \mathrm{O}\right)_{2}(4-n p a)_{2}\right](\mathbf{2})$} \\
\hline Ca1-O11 ${ }^{\mathrm{ii}}$ & $2.3359(16)$ & Ca1-O1 & $2.4355(18)$ \\
\hline $\mathrm{Ca} 1-\mathrm{O} 2^{\mathrm{iii}}$ & $2.3449(16)$ & $\mathrm{Ca} 1-\mathrm{O} 2$ & $2.6516(18)$ \\
\hline Ca1-O21 & $2.4209(18)$ & Ca1-O11 & $2.6636(17)$ \\
\hline Ca1-O22 & $2.4333(17)$ & $\mathrm{Ca} 1-\mathrm{Ca} 1^{\mathrm{iii}}$ & $3.9889(10)$ \\
\hline $\mathrm{Ca} 1-\mathrm{O} 12$ & $2.4346(16)$ & $\mathrm{Ca} 1-\mathrm{Ca} 1^{\mathrm{ii}}$ & $4.0086(10)$ \\
\hline \multicolumn{4}{|c|}{$\left[\mathrm{Sr}\left(\mathrm{H}_{2} \mathrm{O}\right)_{3}(4-\mathrm{npa})_{2}\right] \cdot 4.5 \mathrm{H}_{2} \mathrm{O}(3)$} \\
\hline Sr1-O1 & $2.710(3)$ & $\mathrm{Sr} 1-\mathrm{O} 1^{\mathrm{v}}$ & $2.495(3)$ \\
\hline $\mathrm{Sr} 1-\mathrm{O} 2$ & $2.623(3)$ & Sr1-O6 ${ }^{\mathrm{vi}}$ & $2.605(4)$ \\
\hline Sr1-O5 & $2.773(12)$ & $\mathrm{Sr} 1-\mathrm{O} 2^{\mathrm{vi}}$ & $2.623(3)$ \\
\hline Sr1-O6 & $2.605(4)$ & $\mathrm{Sr} 1-\mathrm{O} 1^{\mathrm{vi}}$ & $2.710(3)$ \\
\hline $\mathrm{Sr} 1-\mathrm{O} 1^{\mathrm{iv}}$ & $2.495(3)$ & $\mathrm{Sr} 1-\mathrm{Sr} 1^{\mathrm{iv}}$ & $4.1940(7)$ \\
\hline
\end{tabular}

Symmetry transformations used to generate equivalent atoms: i) $-x,-y-1$, $-\mathrm{z}+1$; ii) $-\mathrm{x}+1, \mathrm{y}+1,-\mathrm{z}+1$; iii) $-\mathrm{x}+2,-\mathrm{y}+1,-\mathrm{z}+1$, iv) $-\mathrm{x}+1,-\mathrm{y},-\mathrm{z}$; v) $\mathrm{x},-\mathrm{y}, \mathrm{z}+1 / 2$; vi) $-\mathrm{x}+1, \mathrm{y},-\mathrm{z}+1 / 2$. 
Table 3. Hydrogen bonding geometry [ $\left[\AA\right.$ and $\left.{ }^{\circ}\right]$ for $\mathbf{1}, \mathbf{2}$, and $\mathbf{3}$.

\begin{tabular}{|c|c|c|c|c|c|}
\hline $\mathrm{D}-\mathrm{H} \cdots \mathrm{A}$ & d D-H) & $\mathrm{d} \mathrm{H} \cdots \mathrm{A})$ & d D $\cdots A)$ & $<$ DHA & Symmetry code \\
\hline \multicolumn{6}{|c|}{$\left[\mathrm{Mg}\left(\mathrm{H}_{2} \mathrm{O}\right)_{6}\right](4-\mathrm{npa})_{2} \cdot 4 \mathrm{H}_{2} \mathrm{O}(\mathbf{1})$} \\
\hline $\mathrm{O} 3-\mathrm{H} 3 \mathrm{~B} \cdots \mathrm{O} 5$ & $0.870(17)$ & $1.818(17)$ & $2.683(2)$ & 173(3) & $\mathrm{x},-\mathrm{y}-1 / 2, \mathrm{z}+1 / 2$ \\
\hline O1-H1A $\cdots$ O9 & $0.827(16)$ & $1.975(16)$ & $2.785(2)$ & $166(3)$ & $\mathrm{x}, \mathrm{y}, \mathrm{z}$ \\
\hline O1-H1B ‥ O9 & $0.837(16)$ & $2.064(16)$ & $2.890(3)$ & 168(3) & $-\mathrm{x},-\mathrm{y}-1 / 2,-\mathrm{z}+1 / 2$ \\
\hline O9-H9A $\cdots$ O4 & $0.869(17)$ & $1.922(18)$ & $2.778(2)$ & 168(3) & $-\mathrm{x},-\mathrm{y}-1,-\mathrm{z}$ \\
\hline $\mathrm{O} 3-\mathrm{H} 3 \mathrm{~A} \cdots \mathrm{O} 4$ & $0.830(17)$ & $2.27(2)$ & $2.986(2)$ & 144(3) & $-\mathrm{x}, \mathrm{y}+1 / 2,-\mathrm{z}+1 / 2$ \\
\hline O8-H8A $\cdots$ O5 & $0.861(17)$ & $1.928(19)$ & $2.735(2)$ & $156(3)$ & $\mathrm{x}, \mathrm{y}, \mathrm{z}$ \\
\hline O8-H8B $\cdots$ O6 & $0.825(17)$ & $2.186(18)$ & $2.955(18)$ & $155(3)$ & $-\mathrm{x}+1,-\mathrm{y},-\mathrm{z}+1$ \\
\hline $\mathrm{O} 2-\mathrm{H} 2 \mathrm{D} \cdots \mathrm{O} 4$ & $0.857(16)$ & $1.828(16)$ & $2.677(2)$ & 171(3) & $\mathrm{x},-\mathrm{y}-1 / 3, \mathrm{z}+1 / 2$ \\
\hline $\mathrm{O} 2-\mathrm{H} 2 \mathrm{C} \cdots \mathrm{O} 8$ & $0.838(16)$ & $1.873(17)$ & $2.707(2)$ & 172(3) & $\mathrm{x},-\mathrm{y}-1 / 2, \mathrm{z}+1 / 2$ \\
\hline O9-H9B $\cdots$ O8 & $0.857(17)$ & $2.120(18)$ & $2.956(3)$ & $165(2)$ & $\mathrm{x},-\mathrm{y}-1 / 2, \mathrm{z}+1 / 2$ \\
\hline \multicolumn{6}{|c|}{$\left[\mathrm{Ca}\left(\mathrm{H}_{2} \mathrm{O}\right)_{2}(4-n p a)_{2}\right](2)$} \\
\hline $\mathrm{O} 21-\mathrm{H} 10 \cdots \mathrm{O} 1$ & 0.840 & 1.892 & 2.720 & 168.60 & $-\mathrm{x}+1, \mathrm{y}+1,-\mathrm{z}+1$ \\
\hline $\mathrm{O} 21-\mathrm{H} 20 \cdots \mathrm{O} 14$ & 0.840 & 2.259 & 3.096 & 174.84 & $-x+2, y-1 / 2,-z+1 / 2$ \\
\hline $\mathrm{O} 22-\mathrm{H} 30 \cdots \mathrm{O} 12$ & 0.840 & 1.895 & 2.730 & 172.16 & $-\mathrm{x}+3,-\mathrm{y},-\mathrm{z}+1$ \\
\hline $\mathrm{O} 22-\mathrm{H} 40 \cdots \mathrm{O} 4$ & 0.840 & 2.234 & 3.070 & 173.48 & $-\mathrm{x}+1,-\mathrm{y},-\mathrm{z}$ \\
\hline \multicolumn{6}{|c|}{$\left[\mathrm{Sr}\left(\mathrm{H}_{2} \mathrm{O}\right)_{3}(4-\mathrm{npa})_{2}\right] \cdot 4.5 \mathrm{H}_{2} \mathrm{O}(3)$} \\
\hline $\mathrm{C} 7-\mathrm{H} 7 \cdots \mathrm{O} 3$ & 0.93 & 2.63 & $3.359(7)$ & 135.7 & $-\mathrm{x}+1 / 2, \mathrm{y}-1 / 2,-\mathrm{z}+1 / 2$ \\
\hline C5-H5A $\cdots$ O8 & $0.88(2)$ & $2.54(8)$ & $3.322(11)$ & $150(14)$ & $-\mathrm{x}+1, \mathrm{y}-1,-\mathrm{z}+1 / 2$ \\
\hline O6-H6A $\cdots \mathrm{O} 2$ & $0.902(19)$ & $1.86(3)$ & $2.719(5)$ & $159(7)$ & $\mathrm{x},-\mathrm{y}, \mathrm{z}-1 / 2$ \\
\hline O6-H6B … O7 & $0.909(19)$ & $1.97(2)$ & $2.854(6)$ & 163(6) & $-x+1 / 2, y-1 / 2,-z+1 / 2$ \\
\hline
\end{tabular}

$\mathrm{D}=$ Donor and $\mathrm{A}=$ Acceptor.

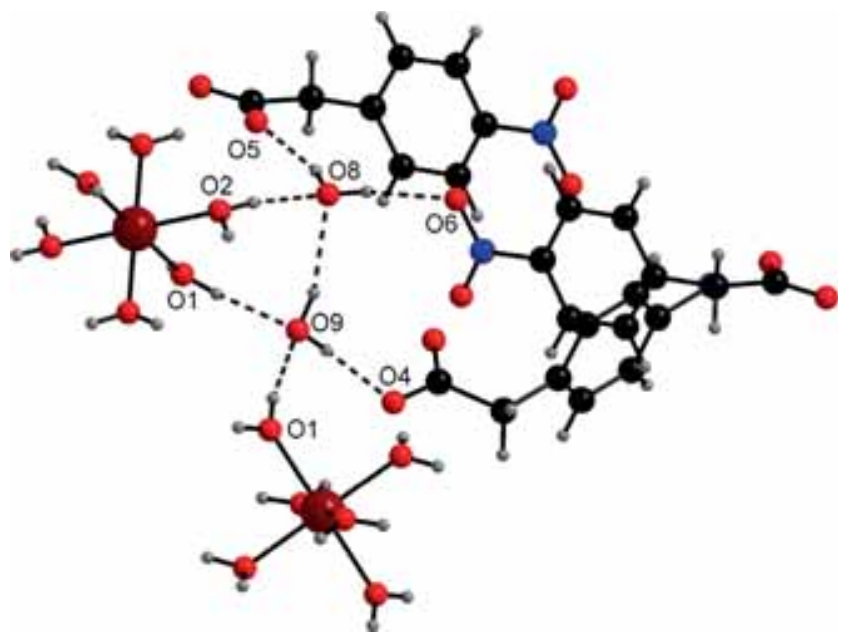

Figure 4. The water dimer $(\mathrm{O} 8, \mathrm{O} 9)$ is $\mathrm{H}$-bonded to two $\left[\mathrm{Mg}\left(\mathrm{H}_{2} \mathrm{O}\right)_{6}\right]^{2+}$ cations and three 4-npa anions (For symmetry relation see Table 4 ).

from 50.83(5) to $155.19(6)^{\circ}$ (Table S2) indicating the distortion of the $\left\{\mathrm{CaO}_{8}\right\}$ polyhedron. The first unique $\mu_{2}$-bridging tridentate 4-npa ligand (O1, O2) which exhibits a $\mu_{2}-\eta^{2}: \eta^{1}$ coordination mode binds to $\mathrm{Ca}$ (II) in a bidentate fashion with $\mathrm{Ca} 1-\mathrm{O} 1$ and $\mathrm{Ca} 1-\mathrm{O} 2$ distances of $2.4355(18)$ and $2.6516(18) \AA$ respectively. The $\mathrm{O} 2$ oxygen is further linked to a symmetry related $\mathrm{Ca}$ (II) center at a distance of 2.3449(16) $\AA$.
A pair of the first unique ligand $(\mathrm{O} 1, \mathrm{O} 2)$ are linked to a pair of $\mathrm{Ca}$ (II) ions with $\mathrm{Ca} \cdot \mathrm{Ca}^{\text {ii }}$ separation of $3.989 \AA$ (Figure S10) which results in the formation of a tricyclic dicalcium-dicarboxylate unit. This is the basic building block of the coordination polymer. This tricyclic unit differs from the well-known cyclic eight membered dimetallic-dicarboxylate unit in several dinuclear carboxylates where the $(-\mathrm{COO})^{-}$functions as a symmetrical $\mu_{2}$-bridging bidentate ligand.

A second independent pair of $\mu_{2}$-bridging tridentate 4-npa ligands (O11, O12) bind to two symmetry related $\mathrm{Ca}(\mathrm{II})$ in an identical manner with $\mathrm{Ca} 1-\mathrm{O} 11$ and Ca1-O12 distances of 2.6636(17) and 2.6516(18) $\AA$ respectively. The O11 oxygen is further linked to a symmetry related $\mathrm{Ca}(\mathrm{II})$ center at a distance of $2.3359(16) \AA$, resulting in the formation of tricyclic dicalcium-dicarboxylate with $\mathrm{Ca} \cdot \mathrm{Ca}^{\mathrm{i}}$ separation of $4.009 \AA$ (Figure S11 in Supplementary Information). Thus the alternating pairs of two crystallographically unique 4-npa ligands connect pairs of $\left\{\mathrm{Ca}\left(\mathrm{H}_{2} \mathrm{O}\right)_{2}\right\}^{2+}$ units into an extended chain with alternating $\mathrm{Ca} \cdots \mathrm{Ca}$ separation of 3.989 and $4.009 \AA$. The formation of a 1-D coordination polymer extending along $a$-axis can be explained as a result of the combined effect of the two unique 4-npa ligands (Figure 4). The binding mode of the carboxylate ligand, as well the terminal waters is very similar to that observed in other $\mathrm{Ca}$ (II) 1-D polymers ${ }^{23}$ like $\left[\mathrm{Ca}\left(\mathrm{H}_{2} \mathrm{O}\right)_{2}(2-n b a)_{2}\right](2-n b a=2$-nitrobenzoate $)$ and 

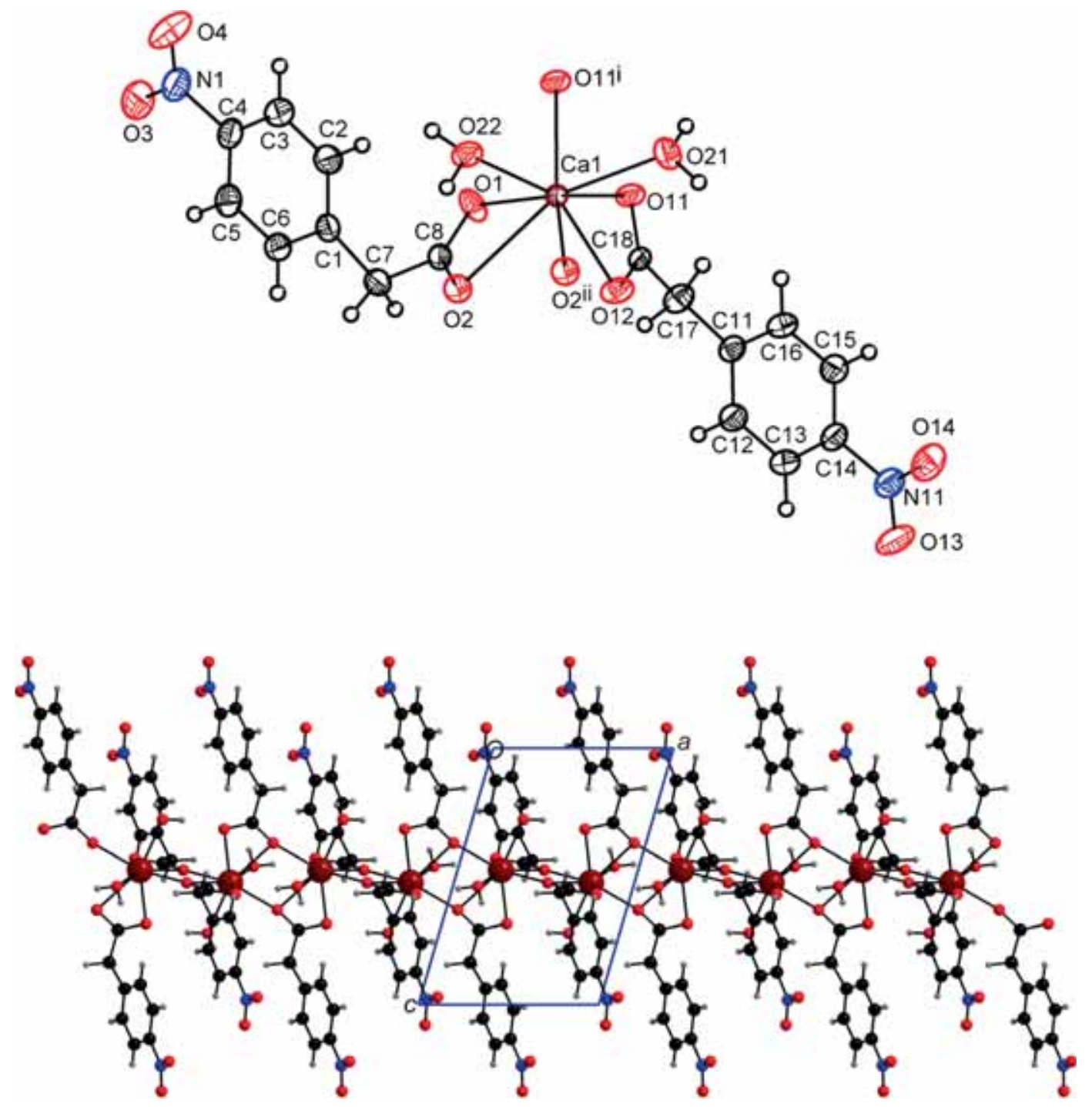

Figure 5. The crystal structure of $\mathbf{2}$ showing the atom labelling scheme and the eight coordination around $\mathrm{Ca}(\mathrm{II})$. Displacement ellipsoids are drawn at the $50 \%$ probability level excepting for the $\mathrm{H}$ atoms, which are shown as spheres of arbitrary radii. Symmetry code: i) $-\mathrm{x}+1, \mathrm{y}+1,-\mathrm{z}+1$; ii) $-\mathrm{x}+2, \mathrm{y}+1,-\mathrm{z}+1$ (top); A portion of the 1-D chain along $a$-axis due to the $\mu_{2}$-bridging tridentate coordination modes of both the unique ligands (botttom).

$\left[\mathrm{Ca}\left(\mathrm{H}_{2} \mathrm{O}\right)_{2}(4-n b a)_{2}\right] \cdot 2 \mathrm{dmp}$ (2-nba = 2-nitrobenzoate; $\mathrm{dmp}=$ dimethylpyrazole). A scrutiny of the crystal structure reveals that the $\mathrm{H}$ atoms of the coordinated water molecules $\mathrm{O} 21$ and $\mathrm{O} 22$ function as $\mathrm{H}$-donors and are linked to the $\mathrm{O} 1, \mathrm{O} 4, \mathrm{O} 12$ and $\mathrm{O} 14$ atoms of the unique 4-npa anions via $\mathrm{O}-\mathrm{H} \cdots \mathrm{O}$ interactions (Table 3).

Compound 3 crystallizes in the centrosymmetric monoclinic space group $\mathrm{C} 2 / \mathrm{c}$. Its crystal structure consists of a unique $\mathrm{Sr}$ (II) located on a twofold axis, two independent coordinated water molecules (O5 and O6) of which $\mathrm{O} 5$ is situated on a twofold axis, an unique 4-npa anion and three lattice water molecules (O7, O8, O9). The geometric parameters of the unique 4-npa ligand are in the normal range (Table S1). The observed Sr-O bond distances (Table 2) vary from 2.495(3) to 2.773(12) and the O-Sr-O angles scatter in a wide range from 48.07(9) to 157.18(16) (Table S2). The hydrogen atoms attached to the lattice waters $\mathrm{O} 7, \mathrm{O} 8$ and $\mathrm{O} 9$ could not be located. The central Sr(II) exhibits nine coordination (Figure 6) and is bonded to six oxygen atoms of four different symmetry related 4-npa anions (as in 2) and three oxygen atoms of three terminal water molecules, resulting in a distorted tricapped trigonal prismatic $\left\{\mathrm{SrO}_{9}\right\}$ coordination polyhedron (Figure S12 in Supplementary Information).

Despite the differing coordination number of the central metal in $\mathbf{2}$ and $\mathbf{3}$, it is interesting to note that the 


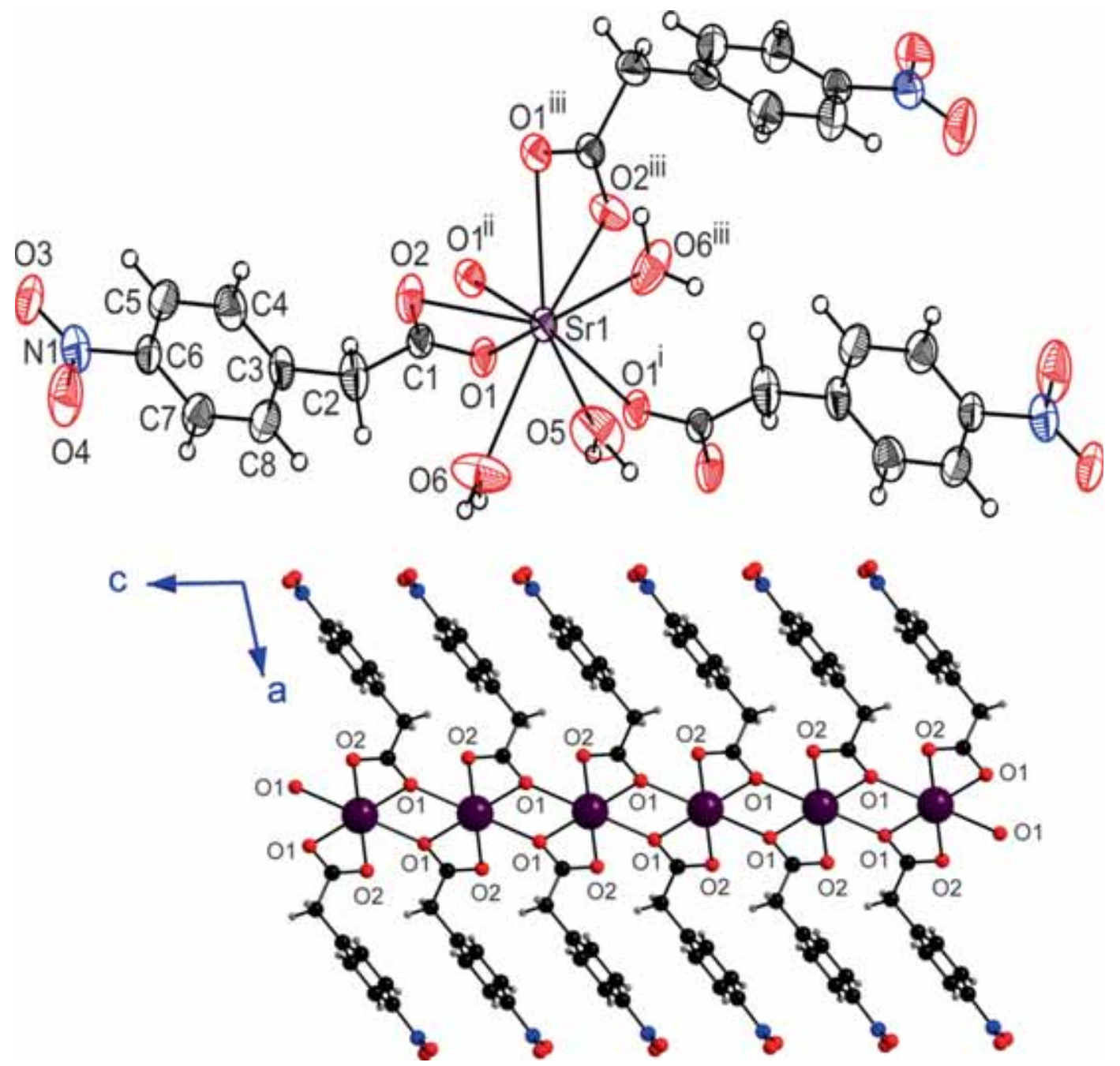

Figure 6. The crystal structure of $\left[\mathrm{Sr}\left(\mathrm{H}_{2} \mathrm{O}\right)_{3}(4-n p a)_{2}\right] \cdot 4.5 \mathrm{H}_{2} \mathrm{O} 3$ showing the atom labelling scheme and the coordination around Sr(II). Displacement ellipsoids are drawn at 50\% probability level excepting for the $\mathrm{H}$ atoms, which are shown as circles of arbitrary radius. For clarity the lattice water molecules are not shown. Symmetry code: i) $-x+1,-y,-z$; ii) $x,-y, z+1 / 2$; iii) $-x+1$, $\mathrm{y},-\mathrm{z}+1 / 2$ (top); A portion of the 1-D coordination polymer extending along $c$ axis due to the $\mu_{2}$ bridging tridentate coordination of the unique 4-npa ligand. For clarity the three coordinated water molecules are not displayed (bottom).

Sr(II) salt of 4-npa 3 is structurally very similar to that of 2. The $\mathrm{Sr}$ (II) ions are linked into an infinite 1-D chain by the unique $\mu_{2}$-bridging tridentate 4-npa ligand
(Figure 5). The presence of three monodentate water ligands coordinated to $\mathrm{Sr}$ (II) in $\mathbf{3}$ (instead of two around $\mathrm{Ca}$ in 2) can explain the nona coordination of $\mathrm{Sr}(\mathrm{II})$.

Table 4. Comparative structural features of the alkaline-earth salts of 4-nbaH and 4-npaH.

\begin{tabular}{llclll}
\hline Compound & S. G. & C.N. & Function of 4-nba or 4-npa & Structure type & Ref \\
\hline$\left[\mathrm{Mg}\left(\left(\mathrm{H}_{2} \mathrm{O}\right)_{6}\right](4-n b a)_{2} \cdot 2 \mathrm{H}_{2} \mathrm{O}\right.$ & $P \overline{1}$ & 6 & Free anion & Monomer & $9 \mathrm{a}$ \\
{$\left[\mathrm{Ca}(4-\mathrm{nba})_{2}\left(\mathrm{H}_{2} \mathrm{O}\right)_{4}\right]$} & $P 2_{1} / c$ & 7 & Monodentate, bidentate & Monomer & $9 \mathrm{~b}$ \\
{$\left[\mathrm{Sr}(4-\mathrm{nba})\left(\mathrm{H}_{2} \mathrm{O}\right)_{7}\right](4-\mathrm{nba}) \cdot 2 \mathrm{H}_{2} \mathrm{O}$} & $P 2_{1} / c$ & 9 & Free anion, bidentate & Monomer & $9 \mathrm{c}$ \\
{$\left[\mathrm{Ba}(4-\mathrm{nba})_{2}\left(\mathrm{H}_{2} \mathrm{O}\right)_{5}\right]$} & $P 2_{1} / c$ & 9 & Bidentate, $\mu_{2}$-bridging bidentate & 1-D Polymer & $9 \mathrm{~d}$ \\
{$\left[\mathrm{Mg}\left(\mathrm{H}_{2} \mathrm{O}\right)_{6}\right](4-\mathrm{npa})_{2} \cdot 4 \mathrm{H}_{2} \mathrm{O}$} & $P 2_{1} / c$ & 6 & Free anion & Monomer & This work \\
{$\left[\mathrm{Ca}(4-\mathrm{npa})_{2}\left(\mathrm{H}_{2} \mathrm{O}\right)_{2}\right]$} & $P \mathrm{i}_{2}$ & 8 & $\mu_{2}$-bridging tridentate & 1-D Polymer & This work \\
{$\left[\mathrm{Sr}(4-\mathrm{npa})_{2}\left(\mathrm{H}_{2} \mathrm{O}\right)_{3}\right] \cdot 4.5 \mathrm{H}_{2} \mathrm{O}$} & $C 2 / c$ & 9 & $\mu_{2}$-bridging tridentate & 1-D Polymer & This work \\
{$\left[\mathrm{Ba}(4-\mathrm{npa})_{2}\left(\mathrm{H}_{2} \mathrm{O}\right)\right]$} & - & - & - & - & This work
\end{tabular}

S. G. = space group; C.N. = coordination number. 
As in 2, a tricyclic distrontium-dicarboxylate unit is the basic building block of the 1-D coordination polymer. In view of the special position of $\operatorname{Sr}($ II) in the crystal structure and an unique 4-npa ligand (unlike two crystallographically independent 4-npa ligands in 2) a single Sr .. Sr separation of 4.194(1) $\AA$ is observed in the 1-D chain due to the linking of pairs of $\left\{\mathrm{Sr}\left(\mathrm{H}_{2} \mathrm{O}\right)_{3}\right\}^{2+}$ units by pairs of the unique 4-npa ligand. In view of the difficulty to locate the $\mathrm{H}$-atoms of lattice water, a discussion of $\mathrm{H}$-bonding in $\mathbf{3}$ is not presented.

A comparison of the structures of $\mathbf{1}$ to $\mathbf{3}$ with the alkaline-earth metal salts of 4-nitrobenzoic acid (4-nbaH) reveals a rich structural chemistry in this group of compounds all of which crystallize in centrosymmetric space groups (Table 4). The $\mathrm{Mg}$ (II) salt of both acids 4-npaH and 4-nbaH contain the octahedral $\left[\mathrm{Mg}\left(\mathrm{H}_{2} \mathrm{O}\right)_{6}\right]^{2+}$ cation. The $\mathrm{Ba}(\mathrm{II})$ salt of 4 -npaH 4 contains a single water molecule unlike $\left[\mathrm{Ba}(4-n b a)_{2}\left(\mathrm{H}_{2} \mathrm{O}\right)_{5}\right]$. The $\mathrm{Ca}$ (II) and $\mathrm{Sr}(\mathrm{II})$ salts of 4-nbaH contain four and seven coordinated water molecules unlike in $\mathbf{2}$ and $\mathbf{3}$, which can also explain their monomeric structure. The present work gives two new examples of structurally characterized compounds viz., 2 and $\mathbf{3}$ both of which are based on a tricyclic dimetal-dicarboxylate unit.

\section{Conclusions}

The synthesis, spectral characteristics and thermal properties of the alkaline-earth metal salts of 4nitrophenylacetic acid are reported along with a description of the structures of three of these salts. The $\mathrm{Mg}(\mathrm{II})$ salt $\mathbf{1}$ is a monomer and is a molecular container for a water dimer. In contrast, the $\mathrm{Ca}(\mathrm{II})$ and $\mathrm{Sr}(\mathrm{II})$ salts are one-dimensional coordination polymers due to the $\mu_{2}$-bridging tridentate nature of the 4-npa ligands in $\mathbf{2}$ and 3.

\section{Supplementary Information (SI)}

Crystallographic data (including structure factors) for the structures of $\left[\mathrm{Mg}\left(\mathrm{H}_{2} \mathrm{O}\right)_{6}\right](4-n p a)_{2} \cdot 2 \mathrm{H}_{2} \mathrm{O}(\mathbf{1})$, [Ca (4-npa $\left.)_{2}\left(\mathrm{H}_{2} \mathrm{O}\right)_{2}\right](2)$, and $\left[\mathrm{Sr}(4-\mathrm{npa})_{2}\left(\mathrm{H}_{2} \mathrm{O}\right)_{3}\right] \cdot 4.5 \mathrm{H}_{2} \mathrm{O}(3)$ reported herein have been deposited with the Cambridge Crystallographic Data Centre as supplementary publication no. CCDC 1482247 (1), CCDC 1482248 (2) and CCDC 1482249 (3). Copies of the data can be obtained, free of charge, on application to CCDC, 12 Union Road, Cambridge CB2 1 EZ, UK. (fax: +44(0)1223-336033 or email: deposit@ccdc.cam.ac.uk). Electronic supplementary information (for Figures S1S12 and Tables S1-S2) is available at www.ias.ac.in/ chemsci.

\section{Acknowledgements}

The authors thank the Sophisticated Analytical Instrument Facility (SAIF), Indian Institute of Technology (IIT) Madras for single crystal X-ray analysis of $\mathbf{1}$ and 3 reported in this paper. Financial assistance to the Department of Chemistry, Goa University at the level of DSA-I under the Special Assistance Programme (SAP) by the University Grants Commission, New Delhi is gratefully acknowledged.

\section{References}

1. (a) Banerjee D and Parise J B 2011 Cryst. Growth Des. 11 4704; (b) Fromm K M and Gueneau E D 2004 Polyhedron 23 1479; (c) Fromm K M 2008 Coord. Chem. Rev. 252 856; (d) Batten S R, Neville S M and Turner D R 2009 In Coordination Polymers: Design, Analysis and Application (Cambridge UK: RSC Publishing); (e) Eddaoudi M, Moler D B, Li H, Chen B, Reineke T M, O'Keeffe M and Yaghi O M 2001 Acc. Chem. Res. 34 319; (f) Burgess K M N, Xu Y, Leclerc M C and Bryce D L 2014 Inorg. Chem. 53552

2. (a) Chanthapally A, Quah H S and Vittal J J 2014 Cryst. Growth Des. 14 2605; (b) Raja D S, Luo J H, Yeh C T, Jiang Y C, Hsu K F and Lin C H 2014 CrystEngComm 16 1985; (c) Arlin J, Florence A J, Johnston A, Kennedy A R, Miller G J and Patterson K 2011 Cryst. Growth Des. 11 1318; (d) Dincă M and Long J R 2005 J. Am. Chem. Soc. 127 9376; (e) Mallick A, Saha S, Pachfule P, Roy S and Banerjee R 2010 J. Mater. Chem. 20 9073; (f) Murugavel R, Anantharaman G, Krishnamurthy D, Sathiyendiran M and Walawalkar M G 2000 J. Chem. Sci. 112273

3. (a) Kang M, Liu T, Wang X, Luo D, Li R and Lin Z 2014 Inorg. Chem. Commun. 44 155; (b) Yang D-L, Zhang X, Yang J-X, Yao Y-G and Zhang J 2014 Inorg. Chim. Acta 423 62; (c) Lian C, Liu L, Guo X, Long Y, Jia S, Li H and Yang L 2016 J. Solid State Chem. 233 229; (d) Srinivasan B R, Shetgaonkar S Y, Dhavskar K T, Sundar $\mathrm{J} \mathrm{K}$ and Natarajan S 2012 Indian. J. Chem. 51A 564; (e) Wang J-H, Tang G-M, Qin T-X, Yan S-C, Wang Y-T, Cui Y-Z and Ng S W 2014 J. Solid State Chem. 219 55; (f) Srinivasan B R, Shetgaonkar S Y and Raghavaiah P 2009 Polyhedron 282879

4. (a) Guan L and Wang Y 2015 J. Solid State Chem. 230 243; (b) Ghazzali M, Khair M, Al-Farhan K and Reedijk J 2014 Inorg. Chim. Acta 409 503; (c) Tan Y-H, Xu Q, Gu Z-F, Gao J-X, Wang B, Liu Y, Yang C-S and Tang Y-Z 2016 J. Mol. Struc. 1119 346; (d) Tahmasian A, Safarifard V, Morsali A and Joo S W 2014 Polyhedron 67 81; (e) Zhang D, Zhang R, Li J, Qiao W and Wang S 2013 Inorg. Chem. Commun. 35 307; (f) Natarajan S, Sundar J K, Athimoolam S and Srinivasan B R 2011 J. Coord. Chem. 64 2274

5. (a) Srinivasan B R, Shetgaonkar S Y and Raghavaiah $P$ 2012 Indian. J. Chem. 51A 1064; (b) Srinivasan B R, Shetgaonkar S Y and Raghavaiah P 2008 J. Chem. Sci. 120 249; (c) Srinivasan B R, Sawant J V and Raghavaiah 
P 2007 J. Chem. Sci. 119 11; (d) Srinivasan B R, Shetgaonkar S Y, Kohli S and Rajnikant 2010 Indian. J. Chem. 49A 1468

6. (a) Murugavel R, Karambelkar V V and Anantharaman G 2000 Indian J. Chem. A39 843; (b) Wiesbrock F, Schier A and Schmidbaur H 2002 Z. Naturforsch. B57 251; (c) Dhavskar K T, Bhargao P H and Srinivasan B R 2016 J. Chem. Sci. 128 421; (d) Dale S H, Elsegood M R J and Kainth S 2003 Acta Crystallogr. 59C m505; (e) Srinivasan B R, Shetgaonkar S Y and Raghavaiah P 2009 Indian J. Chem. 48A 1662; (f) Morgant G, Angelo J, Desmaele D, Dichi E, Sghaier M, Fraisse B, Retailleau P, Brumas V, Fiallo M M L and Tomas A 2008 Polyhedron 27 2097; (g) Indrani M, Ramasubramanian R, Fronczek F R, Braga D, Vasanthacharya N Y and Kumaresan S 2009 J. Chem. Sci. 121413

7. (a) Murugavel R, Karambelkar V V, Anantharaman G and Walawalkar M G 2000 Inorg. Chem. 39 1381; (b) Murugavel R and Korah R 2007 Inorg. Chem. 46 11048; (c) Song W D, Guo X X and Zhang C H 2007 Acta Crystallogr. E63 m399; (d) Srinivasan B R and Shetgaonkar S Y 2010 J. Coord. Chem. 63 3403; (e) Srinivasan B R, Shetgaonkar S Y, Sawant J V and Raghavaiah P 2008 Polyhedron 27 3299; (f) Srinivasan B R, Shetgaonkar S Y and Näther C 2011 Z. Anorg. Allg. Chem. 637 130; (g) Srinivasan B R, Shetgaonkar S Y, Näther C and Bensch W 2009 Polyhedron 28 534; (h) Murugavel R, Baheti K and Anantharaman G 2001 Inorg. Chem. $\mathbf{4 0} 6870$
8. (a) Murugavel R and Banerjee S 2003 Inorg. Chem. Commun. 6 810; (b) Srinivasan B R, Shetgaonkar S Y and Raghavaiah P 2009 Polyhedron 28 2879; (c) Srinivasan B R, Shetgaonkar S Y, Saxena M and Näther C 2012 Indian J. Chem. 51A 435; (d) Odabaşoğlu M and Büyükgüngör O 2007 Acta Crystallogr. E63 m712; (e) Yuan R X, Xiong R G, Chen Z F, You X Z, Peng S M and Lee G H 2001 Inorg. Chem. Commun. 4 430; (f) Senkovska I and Thewalt U 2005 Acta Crystallogr. C61 m448; (g) Srinivasan B R, Shetgaonkar S Y and Ghosh N N 2011 J. Coord. Chem. 64 1113; (h) Yano S, Numata M, Kato M, Motoo S and Nishimura T 2001 Acta Crystallogr. E57 m488; (i) Natarajan S, Srinivasan B R, Sundar J K, Ravikumar K, Krishnakumar R V and Suresh J 2012 J. Chem. Sci. 124781

9. (a) Srinivasan B R, Sawant J V, Näther C and Bensch W 2007 J. Chem. Sci. 119 243; (b) Srinivasan B R, Sawant J V and Raghavaiah P 2006 Indian J. Chem. 45A 2392; (c) Srinivasan B R, Raghavaiah P and Sawant J V 2007 Acta Crystallogr. E63 m2251; (d) Srinivasan B R, Sawant J V, Sawant S C and Raghavaiah P 2007 J. Chem. Sci. 119593

10. (a) Sheng G H, Cheng X S, You Z L and Zhu H L 2015 Synth. React. Inorg. Metal org and Nano-Metal Chem. 45 1273; (b) Ali N, Tahir M N, Ali S, Iqbal M, Munawar K S and Perveen S 2014 J. Coord. Chem. 67 1290; (c) Sharutin V V, Sharutina O K and Senchurin V S 2014 Russian J. Inorg. Chem. 59326

11. Sheldrick G M 2015 Acta Crystallogr. C71 3 